Discussion Paper No. 2002/3

\title{
Proposals for Curbing the Boom-Bust Cycle in the Supply of Capital to Emerging Markets
}

\author{
John Williamson*
}

January 2002

\begin{abstract}
This paper examines what might be done to limit the boom-bust cycle in the flow of capital to emerging markets. Although the paper accepts that some types of capital flow (notably foreign direct investment) are much less problematic in this respect than others (notably short-term bank loans), it argues that influencing the mix would have to be done by capital controls by capital-importing countries rather than supply-side policies. Where supply-side reforms might help is in making some types of flow less unstable: for example, the Buiter/Sibert proposal for a Universal Debt Rollover Option (which needs amendment to alter the term for which rollover might apply); allowing investors with fiduciary responsibilities to hold (though not to buy) bonds of sub-investment grade; penalizing put options in bond contracts and inserting collective action clauses; requiring foreign loans to be denominated in domestic currency; and modifying the remuneration practices of portfolio managers.
\end{abstract}

Keywords: capital flows, boom-bust cycle, UDROP, collective action clauses

JEL classification: F34

Copyright (c) UNU/WIDER 2002

*Senior Fellow, Institute for International Economics, Washington DC

This study has been prepared within the UNU/WIDER project on Capital Flows to Emerging Markets since the Asian Crisis, which is co-directed by Professor Stephany Griffith-Jones and Dr Ricardo FfrenchDavis. 


\section{Acknowledgements}

The author acknowledges the helpful discussion of other participants in the UNU/WIDER workshop held in Santiago in March 2001.

UNU World Institute for Development Economics Research (UNU/WIDER) was established by the United Nations University as its first research and training centre and started work in Helsinki, Finland in 1985. The purpose of the Institute is to undertake applied research and policy analysis on structural changes affecting the developing and transitional economies, to provide a forum for the advocacy of policies leading to robust, equitable and environmentally sustainable growth, and to promote capacity strengthening and training in the field of economic and social policy making. Its work is carried out by staff researchers and visiting scholars in Helsinki and through networks of collaborating scholars and institutions around the world.

UNU World Institute for Development Economics Research (UNU/WIDER)

Katajanokanlaituri 6 B, 00160 Helsinki, Finland

Camera-ready typescript prepared by Jaana Kallioinen at UNU/WIDER

Printed at UNU/WIDER, Helsinki

The views expressed in this publication are those of the author(s). Publication does not imply endorsement by the Institute or the United Nations University, nor by the programme/project sponsors, of any of the views expressed.

ISSN 1609-5774

ISBN 92-9190-124-5 (printed publication)

ISBN 92-9190-125-3 (internet publication) 


\section{Introduction}

The problem of boom-bust in capital flows to emerging markets is well recognized. The present paper will examine which forms of capital flow are particularly problematic in this respect and which are more stable, and will then examine what might be done to stabilize the overall flow of private capital. The possibilities here may be decomposed into altering either the volume or the behaviour of the various types of flow. There is not much that can be done from the supply side to alter the relative volume of different forms of capital flow; such policies as are available in this respect concern the capital controls that may be exercised by capital-importing countries, a subject dealt with in José Antonio Ocampo's paper (2001). Hence this paper focuses on a discussion of ways in which supply-side reforms might be able to alter the behaviour of certain types of capital flow.

\section{Diagnosis of where the problems lie}

Conventional wisdom has long held that some forms of capital flow are much more liable to rapid reversal than others. This view was challenged by Claessens et al. (1994), who failed to find statistically significant differences in the time series properties of different forms of capital flow (FDI, portfolio equity, long-term, short-term, banks, government, and private). But in his discussion of this paper1 Guillermo Calvo presciently pointed out that the authors' estimates of volatility (which essentially focused on the second moment of the time series) might fail to give due weight to what is of most importance, the possibility of occasional major disruptions (which are measured by higher moments in the time series). To judge by what happened in East Asia during its recent crisis, where FDI was largely maintained while bank capital reversed on a grand scale, it is indeed proper to worry much more about the volatility of some forms of capital flow than of others. A new study by Robert Lipsey (2001) has confirmed the conventional wisdom about the relative stability of FDI flows. This is not to say that multinationals will refrain from shifting working balances among currencies depending on their view of macroeconomic prospects, but just that such shifts are unlikely to be large relative to the total sum sunk in capital investment. Large-scale reversal is in most cases physically impossible.

Bank lending, which constituted the principal component of the capital flow reversal in East Asia, was at the other extreme to FDI. The same thing was true in the debt crisis. Common sense (and received wisdom) would suggest that short-term bank loans are more prone to instability than long-term loans, an expectation that would again seem to have been verified by the evaporation of inter-bank credit lines experienced by Korea in late 1997. One reason that Claessens et al. failed to find any distinction in volatility based on maturity may be that they lumped trade credits with other short-term credits extended by banks. The usual belief is that trade credits are one of the less volatile sources of finance, despite the fact that each individual credit is short-term, because

1 More clearly in the oral version than in the written version that appears after the Claessens-DooleyWarner paper. 
they are constantly renewed as new trade transactions need to be financed. It is the residual item, bank claims that have a short term to maturity that are not trade-related, that conventional wisdom holds to be particularly volatile.

It has been argued by Avinash Persaud (2000) that the recent moves to strengthen bank risk management and prudential standards, and increase transparency, may even intensify the problem of pro-cyclical behaviour by banks. He points to the increasing use of DEAR (daily earnings at risk) limits as a tool of risk management that seems perfectly rational when viewed from the standpoint of the individual bank, but that can work to increase volatility. The DEAR sets a limit on how much the bank is prepared to risk losing over the following day with, say, one percent probability.

It is calculated by taking the bank's portfolio... and estimating the future distribution of daily returns based on past measures of market correlation and volatility. Both rising volatility and rising correlation will increase the potential loss of the portfolio, increasing DEAR...When DEAR exceeds the limit, the bank reduces exposure, often by switching into less volatile and less correlated assets.

Daily publication of statistics can accelerate and intensify the spread of any bad news that may break, with declining asset values and increasing volatility serving as sophisticated positive feedback mechanisms.

So much for the easy cases. The interesting question concerns the volatility of other claims that can be sold quickly, notably portfolio equity and long-term bonds. There was indeed a reduction in the flow of portfolio investment to East Asia in 1997-98, although nothing like the reversal seen in the case of bank lending. There is an important reason why one should expect less volatility in the case of portfolio equity than in the case of short-term loans: the price of the relevant asset (shares) can adjust, rather than all the adjustment taking place in the volume. Indeed, if a shock has the same impact on the future expectations of domestic and foreign investors in shares, then one would expect that all the resulting adjustment would show up in a change in share prices, with no consequences for capital flows or exchange rates. (Large and abrupt declines in share prices can also create problems, especially where expectations are endogenous and extrapolative rather than exogenous and regressive. Personally I would nonetheless argue that the stock market is a rather good place to absorb the impact of changes in expectations, because the links from the stock market to the real economy tend to be weak in the short term.) It is only when foreign investors lose their nerve about the prospects for a country or region in a way that domestic investors do not, as in East Asia in 1997, that one should expect an impact on capital flows.

Empirical evidence is not as reassuring as those theoretical considerations might have led one to expect. Froot et al. (1998) found evidence that equity flows are persistent over time and that investors often buy (sell) in response to a price rise (decline). Kaminsky et al. (1999) concluded that mutual funds have had a destabilizing impact and have helped spread contagion in Latin America. It also seems that Chilean pension funds made almost no use of their new rights to invest abroad during Chile's capital inflow surge, but then began placing funds abroad on a big scale when capital flow reversal occurred after the East Asian crisis (Ffrench-Davis and Tapia 2001). Bekaert et al. (1999) find that when equity capital leaves it does so faster than when it entered, suggesting that it is not after all so difficult to find domestic purchasers. Only Barth and 
Zhang (1999) found no evidence that foreign investors had played a destabilizing role: indeed, they claim that in only one month (December 1997, see p.201) were mutual funds net sellers in the four main crisis countries of East Asia. And while they refer to some investors as having been attracted into the Asian markets with a short-term horizon seeking high returns' (p.199), they also argue that the figures show that foreign institutional investors were slow to exit after the crisis started, as a result of which they lost a lot of money (pp.202-5).

Korea has a particularly rich data set (although there are doubts about its reliability) that has enabled investigators to trace the strategy of individual investors in a way that is not possible elsewhere. The first study to exploit this source, that of Choe, Kho, and Stulz (1999), suggested that while the trades of foreign investors were destabilizing before the crisis, the foreign investors acted as a stabilizing force during the crisis. However, their data extended only briefly into the crisis period, and the subsequent study of Kim and Wei (1999a) concluded that foreign institutional and (even more) individual investors had been positive feedback traders (i.e. had bought in response to a price rise and sold in response to a price fall) both before and during the crisis. The only exception to this procyclical behaviour was prior to the crisis by those foreign institutions that had a Korean office; these were contrarian traders (i.e. they had tended to buy recent losers and sell recent winners). Kim and Wei also calculated that a contrarian strategy would have been more profitable than a positive-feedback strategy, which suggests that the Koreans who must perforce have been following such a strategy (as the counterpart of the foreign positive-feedback strategies) must have made money, or at least lost less money, as compared to the foreigners. Kim and Wei (1999b) also found evidence that mutual funds based in the USA and the UK engaged in positive-feedback trading, and to some extent in herding behaviour, in Korea in 1997-98.2

Note that all these studies focus on portfolio equity investment in the stock markets of emerging countries. As Barth and Zhang (1999) point out, portfolio equity is invested in emerging markets through two other channels as well. One is in the form of private (i.e. non-traded) equity. Barth and Zhang's Figure 6.2 suggests that in East Asia this is a small but rather stable flow. The other is by emerging market companies listing their shares on international markets like New York (of dominant importance for Latin American companies) or London (ditto for South African companies). Barth and Zhang's Tables 6-12 show that international placements became of major importance in the mid-1990s and peaked in 1997, before falling substantially in 1998. The decline in international placements was nevertheless modest compared to that in foreign investment in local stock markets: it went from US\$ 6 billion in 1996 to US\$ 11 billion in 1997 to US\$ 4 billion in 1998, while investment in local markets fell from US\$ 9 billion in 1996 to minus US\$ 3 billion in 1997 to plus US\$ 1 billion in 1998.

Authoritative sources assert that the sharp reduction in the inflow of portfolio equity to East Asia during the 1997 crisis reflects quite different behaviour on the part of two different groups of investors (an account consistent with the report of Barth and Zhang 1999, p.197). The withdrawals were made by global funds that had been searching for

2 They set out to test the hypotheses that mutual funds based offshore are more prone to heavy trading, to positive (procyclical) feedback trading, and to herding behavior than are onshore funds. They found to their surprise that funds based in the USA and the UK were actually the ones more prone to positive feedback trading and to herding behavior, although the offshore funds did tend to trade more heavily. 
high-yielding investments and had been attracted by the high yields in East Asian share markets prior to the crisis, but which had not advertised their investments in emerging markets. They were embarrassed to be holding assets whose value collapsed, and got out as fast as they could, before their holdings became widely known and criticized. But, according to this account, the holdings by funds that advertised that they were investing in emerging markets remained steady, and may even have picked up some of the shares being sold by the former group, perhaps to sustain their target asset allocations. These investors are in emerging markets for the long haul, aware that these are inherently risky markets that will have downs as well as ups, and neither the managers of the funds nor their investors panicked. Worryingly, Griffith-Jones (2001) suggests that the importance of global funds has in recent years increased relative to that of dedicated emerging market funds.

Does Milton Friedman's famous 1953 theorem which says that destabilizing speculators must lose money (because to destabilize a market one must buy near the peak and sell near the trough, whereas making money requires the opposite) reassure one that funds that amplify the boom-bust cycle will lose money and so at least enrich domestic investors? Not necessarily. One possibility is that alluded to earlier, that the counterpart to the sales by foreigners will be purchases by other foreigners. But even if foreign portfolio investors do indeed on balance follow the herd, buying when the market is rising and selling when it is falling, so that in total domestic investors are selling when the market is rising and buying when it is falling, it does not necessarily follow that the foreigners will lose money. Buying on a rising market and buying near the peak are not the same thing; speculators who are alert to changes in trend may be able to quit buying, and sell out, soon after the peak is past, and make money. The empirical studies reported above offer a contradictory verdict on whether many foreign investors in fact got out of East Asia sufficiently quickly to have saved their skins. What is quite clear is that foreign investors in total lost an enormous sum of money in East Asia, at least on paper: some US\$ 166 billion during 1997, according to the calculations of Barth and Zhang (1999, p.204).

Much the same analysis applies to long-term bonds, whose prices also fluctuate in response to changes in expectations in such a way as to ensure that the total stock of bonds continues to be willingly held. However, nominally long-term bonds sometimes include put options, giving the holder the right to demand early repayment at his discretion on certain dates. If such dates coincide with a crisis, then the loan tends to disappear just when it is most needed, as happened in Korea in late 1997.

While the holdings of those who buy emerging markets assets to hold them may not be as stable as one might wish, a largely separate and perhaps more acute problem is posed by overtly speculative activities. Hedge funds, institutions whose managers quite consciously range the world looking for market anomalies or good speculative bets that are expected to yield high returns and which are totally unregulated on the ground that only rich people who do not need protection invest in them, are the archetype. The proprietary trading desks of investment banks and other financial companies (commercial banks, securities firms, and even a few insurance companies) behave similarly. It is the hedge funds that were the butt of Prime Minister Mahathir's criticisms in 1997, but Henry Kaufman (2000) asserts that virtually all investment institutions have now adopted this investment style for at least an important part of their activities. 
The actions of these investors in 1998 came under critical official scrutiny in the report of the Market Dynamics Study Group of the Financial Stability Forum's Working Group on Highly Leveraged Institutions (Financial Stability Forum 2000). The Group examined the 'possible destabilizing impact of large and concentrated HLI positions (in 1998) and the implications for market integrity of various aggressive practices' (p.97). The economies with which they were concerned were Australia, Hong Kong, Malaysia, New Zealand, Singapore, and South Africa, although New Zealand and Singapore expressed less concern than the other four. These countries experienced strong pressures in their foreign exchange and domestic financial markets in the middle of 1998. By then it was pretty clear that all the currencies (except the Hong Kong dollar, which is fixed with a currency board) were undervalued, yet the speculative pressures were all for further depreciation. This was the time when the Hong Kong Monetary Authority upset the free market fundamentalists by buying up a big chunk of the equity market to defend itself against the double play. The pressures were relieved in September and gave way to a sharp rebound in early October as the HLIs were forced to deliver following the collapse of LTCM.

The report documents the fact that a handful of HLIs established such large short positions in these currencies as to stretch the capacity of natural counterparties (like exporters) to offset their positions. The question that an economist instinctively asks is how they expected to make money out of such operations. It is one thing to have the market power to force a price below its fundamental value, it is quite another to make money out of forcing it there. To do that, one needs to be able to get others to sell the currency at even more undervalued levels, so as to be able to close out one's short sales at a profit. In the case of Hong Kong, the HLIs sought to profit by the 'double play', which involved selling equities short and then selling the Hong Kong dollar short, relying on the automatic interest rate rise generated by the currency board rules in order to force equity prices down. This would have yielded them a profit even if the Hong Kong dollar was not devalued as long as the Hong Kong Monetary Authority played by the rules of the game (which it didn't, because it intervened to buy the equity index). But in other cases the HLIs could have expected to profit only if they panicked the market.

The evidence is that that is exactly what they tried to do. The report discusses aggressive practices, in the form of 'talking the book', which means disseminating rumours designed to influence prices so as to benefit the positions already taken. A manager of an HLI large enough to have significant market power might make negative comments on a currency that would discourage other market participants taking contrary positions. Some financial institutions are reported to have published 'research conclusions' designed to influence the market ('positions led research rather than vice versa', p.106). They exploited momentum trading by other participants by trading heavily at illiquid hours, apparently attempting to move rates rather than to get transactions executed at the best possible prices. HLIs at times took correlated positions, both within and across markets, one might presume by design though no one could prove that it was not by coincidence. These tactics at times succeeded in driving many regular traders out of the market for fear that they would be overwhelmed by HLIs that were not playing by the normal rules of a competitive market. At other times other market participants were 'emboldened to add to momentum' (p.107), or at least not to stand in the way of positioning by large HLIs. And some HLIs were able to take advantage of knowledge of the impact of price changes, e.g. proprietary trading desks 
were able to take advantage of knowledge as to when declining bond prices would require bond sales by swap desks, or they might be able to push rates through levels that they knew would trigger stop-loss orders or knock-out options.

The study group did not reach consensus on the role and importance of the aggressive trading practices that it documented, but it is pretty clear that most members of the group concluded that they threatened market integrity. After making a host of careful qualifications, the report concluded:

The group is concerned about the possible impact on market dynamics of some of the aggressive practices cited in the case-study economies during 1998; it is not, however, able to reach a conclusion on the scale of these practices, whether manipulation was involved and their impact on market integrity. Some group members believe that the threshold for assessing manipulation can be set too high and that some of the aggressive practices raise important issues for market integrity. They are of the view that there is sufficient evidence to suggest that attempted manipulation can and does occur in foreign exchange markets and should be a serious concern for policymakers.

It is difficult to imagine a much more damning indictment coming from a group of officials.

\section{Strategic issues}

The focus here will be on making individual types of capital flows less unstable, rather than on trying to influence the mix of different forms of capital flows (a topic treated by Ocampo's paper 2001). A good place to start considering what might be done in this connection is by considering why portfolio equity seems to have disappointed the expectations of those like me who argued it was unlikely to pose problems of instability. I conjecture that the reason lies in the way that financial markets operate. Consider what Henry Kaufman (2000, p.61) recently wrote:

As markets and assets have changed dramatically with the emergence of a new global financial system, so has the composition of financial institutions themselves. The power and influence of traditional commercial banks, savings and loans, and insurance companies have diminished, while a new breed of institutional participants has come to the fore. These institutions are distinguished by their emphasis on shortterm investment performance, their heavy use of leverage, and their willingness to move in and out of markets - whether equities, bonds, currencies, or commodities - in a relentless quest to maximize returns. The new breed includes the often-reviled hedge funds, although they are neither the sole nor the leading contestants. In fact, most prominent banks, securities firms, and even a few insurance companies possess departments that emulate the trading and investment approach of the hedge funds. Even the corporate treasuries of a number of non-financial corporations are engaged in this activity. Once arcane and exotic, the hedge fund approach to investment has been mainstreamed. 
In other words, the financial markets are currently dominated by investment managers with a short-termist philosophy, based on the truism that to maximize returns in each and every short run necessarily maximizes returns over the long run as well. What it clearly does not maximize is the usefulness of financial markets to those who raise funds from them.

A key question is whether short-termist management is really in the interest of the ultimate investors, the individuals who buy mutual funds and the institutions whose endowments and working assets are under management. The contrary argument has been developed by David Swensen (2000), the chief investment officer of Yale University who inter alia manages its endowment. The basic argument is that shorttermist management risks whiplash (selling an asset just before it rises or buying it just before its peak) and undermines the likelihood of systematic contrarian investment (buying what is currently out of fashion and selling what is currently in fashion). Such actions often seem unthinkable in the short run, but the evidence is that on average they are more often right than wrong.

The basic characteristics of a long-term investment strategy as laid out by Swensen involve a strategic decision to divide the portfolio among asset classes in target proportions based on long-run risk-return characteristics. Within each asset class, assets are managed by individual managers who are selected according to their performance relative to the rest of the asset class, as in the conventional short-termist approach. But the strategic element in this strategy leads to results exactly contrary to those yielded by the DEAR approach described above. For example, a market run on emerging market assets leads to purchase of more such assets, in order to restore the proportion of the portfolio in that asset class to its target share, rather than to the sale of similar assets, as under DEAR. This tends to stabilize markets rather than destabilize them.

Which strategy yields better results to the ultimate investor? The Yale endowment managed by David Swensen has indeed achieved superior returns. But so have most of the hedge funds, the example par excellence of the short-termist approach. What both have in common is superior management. One would need much more systematic comparison to be able to draw any strong conclusion about the superiority of one approach over the other, from the standpoint of its ability to generate results to the ultimate investor. What one can surely say is that there is no reason to accept as axiomatic the self-serving claim of the short-termists that any approach other than theirs is self-evidently at the cost of the investor.

Perhaps the biggest difficulty with the long-term approach concerns the difficulty of monitoring the performance of investment managers in real time. If one abandons the discipline of regular comparisons with the behaviour of a peer group, poorly performing managers get too much opportunity to plead that they are currently invested in what is unfashionable and that patience is needed to give time for the market to realize the error of its ways. But the best antidote to the lack of that discipline is to demand the presence of an alternative form of discipline, in the form of a coherent long-term strategy such as that described above. Trustees are those who should ensure that this alternative discipline is in place; one problem is that they can be as prone to panic (the great enemy of contrarian investing) as anyone else. 
Even though at this stage I cannot prove it, the presumption is that ultimate investors and borrowers share a common interest in securing a shift from the currently dominant mode of short-termist investment management to the long-term strategy described above. They share a common enemy, in the form of the portfolio management industry as currently organized. This has an interest in maintaining remuneration largely based on frequent short-term comparisons with the performance of their peers, which generates high remuneration, and lots of portfolio churning, so as to generate commission income to pay the high salaries. The question to consider is whether anything can be done through public policy to tilt the balance of advantage toward those investment managers who employ a long-term strategy. The remainder of the paper consists of brief explorations of several possible ideas that might help push things that way.

\section{An amended UDROP}

Perhaps the most promising possibility in this connection is presented by an idea that has surfaced as a result of the repeated experience of financial crises and the costs they impose on their victims: that it should be possible to declare a standstill on debt service payments. Many observers have come to feel that, with private capital flows as large and volatile as they now are, the only response to the outbreak of a currency crisis is to create the ability to interrupt a run by force majeure. This conclusion has been reinforced by the view that the countries that came out of recent financial crises relatively quickly and least badly scarred are those (notably Korea and Brazil) where the authorities quickly negotiated a lengthening of debt maturities with an important class of creditors. The thought is that in many of these crises the problem is one of illiquidity rather than insolvency; the country would be capable of honouring its obligations without a cut in their present value ('debt relief') if only the repayment obligations were spread out over a longer time period, but the incentive of any individual creditor is to cut and run. In this situation, one needs to solve the creditors' coordination problem by giving them an incentive to come to the table and quickly negotiate a debt restructuring. A standstill could provide the incentive, by eliminating the option of cut and run. The problem is how to provide that possibility when it is needed without destroying the principle of the sanctity of debt contracts that underlies any capital market. Note also that successful design of a standstill mechanism might have the attractive feature of sabotaging the investment strategy of the short-termists while leaving long-term strategies relatively unscathed.

To consider the possibilities here, start with the most concrete proposal for a standstill that has yet been tabled, the UDROP proposal of Willem Buiter and Anne Sibert (1999). UDROP is the acronym for Universal Debt Rollover Option with a Penalty. In their own words:

All foreign-currency IOUs must have a rollover option attached to them. This includes private and sovereign, long-term and short-term, marketable and non-marketable, negotiable and non-negotiable debt, including overdrafts, credit lines, and contingent claims...All borrowers, public and private, must be given the option... 
The option would entitle the borrower, at his sole discretion, to extend maturing debt for a specified period (say three or six months) at a penalty rate. The borrower would be entitled to the rollover only if the debt in question had been serviced in full, barring the final repayment...

We expect the penalty spread and other features of the rollover contract to be negotiated between debtors and creditors, rather than decreed by a government or international body (pp.231-32).

Buiter and Sibert emphasize that their scheme is intended only to help an otherwise solvent borrower that is unable to roll over its foreign currency debt because of a liquidity crisis. However, most crises are not pure panics that are resolved simply by the passage of time. They arise when creditors develop doubts about the ability of debtors to service their debts on the contractually agreed terms, and they end when those doubts are resolved. One has to ask why a six-month delay without any restructuring of debt beyond that point should allay such fears: surely the presumption is that the debtor's condition will be essentially the same as it was when the UDROP was exercised, which suggests a danger that all it would accomplish would be to delay the crisis.

Nevertheless, an amended version of the UDROP proposal would be a natural complement to the sort of ideas for an international bankruptcy mechanism that were recently floated by Anne Krueger (2001). Enforcing a standstill as she envisages would be much easier if all international loans included a clause that could be invoked to extend the maturity of the loan in the event of the borrowing country facing a crisis. To transform this into a proposal that could serve the function of a standstill, however, one would need to alter the term for which the rollover would apply.

The diagnosis of what is needed to end a debt crisis that was offered above suggests that the need is likely to be for an extension of much more than six months. The three-year extension of maturities that was negotiated between Korea and its bank creditors at the end of 1997, would seem much more likely to be typical. In fact, this is a dimension that probably should not be prespecified, but negotiated between debtor and a creditor committee $a d h o c$ as and when the rollover option is invoked. The creditors will presumably seek the shortest rollover period that gives assurance of allowing the debtor to restore its liquidity and exit from crisis. But if they are recalcitrant in agreeing to a realistic time frame, the debtor would be relieved of the obligation of paying amortization pro tem. The incentive for the debtor to agree to the shortest realistic period for the rollover is to preserve its standing in the capital markets.

Creditors have reacted adversely to the UDROP idea. If it turned out they are so strongly averse to it as to bring lending to a halt, one might exempt long-term loans above a certain maturity. Trade credits might be allowed to satisfy the requirement by a provision that a given volume of credits revolve over time, on the model of the banks' 1998 agreement with Brazil. But the loans that should not be exempted, no matter how severe the impact on volume, are short-term loans. It is true that UDROP would add to the risk of short-term lending to a debtor whose medium-term position looks doubtful, but that is the point. Short-termist lenders find it more difficult to persuade themselves that they can buy short-term assets and then win the race to the exits if things go wrong. The game where investment bankers advise their clients that it is safe to buy short-term assets from country $\mathrm{X}$ because it looks safe enough for the next $\mathrm{n}$ months would be 
undercut. Only investors willing to make a relatively long-term commitment would invest in emerging market loans, and those are the only investors worth having.

UDROP would not, of course, resolve the problem posed by short-termist investors in the equity markets. Perhaps that is a problem that we are going to have to live with.

\section{Trading guidelines for foreign exchange markets}

In reaction to the criticisms of the Sub-Group on Market Dynamics of the Study Group on Highly Leveraged Institutions of the Financial Stability Forum that was referred to above, a group of 16 leading banks announced a voluntary code of conduct in February 2001. The idea is that if all the leading banks subscribe to these principles, and deny liquidity to parties whom they believe to be violating them, then there will be no further incidents similar to those of August-September 1998. The principles they announced are:

i) Banks should be sensitive to market risk and credit management and pay special attention to the financing of trades in a currency experiencing high volatility.

ii) Foreign exchange managers should pay particular care in executing orders in times of volatility and market-makers may reserve the right to refuse customer transactions that they feel may further disrupt or intend to disrupt markets.

iii) Stop/loss orders. Foreign exchange managers should communicate frequently with customers on market developments, especially regarding individual trigger levels.

iv) Caution should be taken that customers' interests are not exploited when financial intermediaries trade for their own account.

v) Institutions should be attentive at all times to ensure the independence and integrity of any market-related research they publish.

vi) Financial intermediaries should implement rigorous guidelines on the handling of rumours. Dealers should not relay information that they know is false or suspect may be inaccurate.

vii) Manipulative practices by banks with each other or with clients constitute unacceptable trading behaviour.

viii) Foreign exchange trading management should prohibit the deliberate exploitation of electronic dealing systems to generate artificial price behaviour.

It is rather sad that it is necessary for leading financial institutions to announce that in future they will consider it bad form to manipulate their clients or to publish research that lacks integrity, but perhaps we should be thankful for small mercies. At present there appears to be no intention to supervise whether the banks live up to their voluntary code. It would be worth adding this to the tasks imposed on supervisors. 


\section{Limitation to investment-grade bonds}

Investors with fiduciary responsibilities, like insurance companies, are forbidden (at least in the United States) to hold bonds that are less than investment grade. At first glance that may seem sensible, since it precludes these institutions abusing their position of trust by using their investors' money to buy risky assets. What does not make sense, however, is that this requirement is specified in terms of what they may hold rather than what they may acquire. The difference can be crucial. In late 1997, insurance companies holding Korean bonds were forced by this requirement to sell them in the midst of the market implosion, when the credit rating agencies had panicked and suddenly cut Korea's rating to below investment grade. The holders were not allowed to exercise their judgement as to whether Korean bonds remained a good investment (which they certainly were after their price had collapsed), they were forced to sell and add to the pressures on Korea, at the cost of their clients. Any such requirement should be redrafted to limit what fiduciary investors can buy rather than what they can hold. That would prevent their being forced to sell in response to a credit downgrading, as happened in Korea in late 1997. As well as making bond lending somewhat more stable, this change would reduce the premium on short-termist assessment of whether and when credit ratings may change.

\section{Put options in bond contracts}

A five-year loan with a put option exercisable in six-months' time is not really a fiveyear bond; from an economic standpoint it is a short-term, six-month loan with a rollover provision if the lender consents. It should be counted as such in the statistics. Correct reporting would force both the borrowers and their national authorities to recognize the risks that are being taken. One would expect that this would diminish the attractiveness of agreeing to the inclusion of put options in bond contracts, and hence lengthen the effective maturity of bonds.

\section{Collective action clauses}

One of the reasons that helped motivate the switch from bank lending in the 1970s to bond lending in the 1990s, was without much doubt the lesser vulnerability of bonds to restructuring when a country ran into debt servicing problems. This was based in particular on provisions that were introduced into New York law in 1939 to restrain abusive debt buybacks that had the effect of arbitrarily expropriating some creditors (Buchheit and Gulati 2000, pp.66-7). The provisions in question require unanimous consent by the bondholders to any change in the terms of the payment clauses, which are those clauses that specify the sums to be paid in debt service and the dates when payments are due. This gives a single recalcitrant bondholder - or a vulture fund that buys up distressed debt - the ability either to prevent a debt reconstruction when that is necessary, or else the ability to insist on full repayment even when other holders have agreed to accept less. Indeed, such a bondholder can normally expect to demand, and win from the courts, accelerated repayment, when normal debt service was interrupted before the debt reconstruction. Naturally the prospect that some creditors would not make sacrifices when others did, and that the debtor would indeed be able to service the 
claims of the holdouts precisely because the others agreed to accept a write-down of their claims, made the majority reluctant to endorse bond restructurings. It could even be that the debtor would be unable to honour the revised debt terms because of the payment it was forced to make to the holdout bondholders.

As long as bonds were a small part of the total claims outstanding, it was simpler to allow them to remain intact when bank claims were restructured. It was clear that this could not continue if debtors ran into trouble when bonds had become a large part of the total debt, and indeed the official sector has in recent years started to call for private sector involvement in debt workouts (Group of 10, 1996). Led by Eichengreen and Portes (1995), a number of economists had already at that time started to advocate the introduction of collective action clauses 3 into all bond contracts in order to facilitate the restructuring of bonds when necessary. When this proposal was first mooted, there were dire predictions from some of the New York-based lenders, echoed by some of their clients, that any attempt to include such clauses would bring lending to a halt, or at the least lead to drastic increases in interest rates. Then someone realized that about onethird of such bonds, namely most of those signed in London, already include such clauses. Eichengreen and Mody $(2000 \mathrm{a}, \mathrm{b})$ therefore examined whether the inclusion of such clauses had resulted in higher interest rates to the borrowers, as per the prediction. It turned out that the impact was modest and also, interestingly, that the direction of impact depended upon the borrower's creditworthiness. Countries with poor credit ratings did indeed have to pay somewhat more to borrow with the added security of collective action clauses, presumably reflecting lender concern that a lack of willingness to pay might lead borrowers to abuse the clauses, even when they would have been able to pay. But countries with good credit ratings actually paid somewhat less, presumably reflecting lender recognition that the clauses would reduce the cost of restructuring debt (and the possible interruption in debt service payments while this happened) in the remote contingency that the countries should encounter an inability to pay so that restructuring proved necessary.

The lawyers have now found a way of reconstructing bonds issued under New York law, even without collective action clauses (Buchheit and Gulati 2000). The key is to accompany the offer to swap old bonds for the new bonds that contain the revised payment terms by amendments to the non-payment clauses of the old bonds in ways that make these much less attractive and impede any holdout bondholders from successfully litigating to demand continued or accelerated payment. For example, the old bonds may be de-listed, the waiver of sovereign immunity may be withdrawn, and negative pledge protection may be removed, all without the need for unanimity that prevents revision of the payments clauses. Since these disfiguring amendments to the terms of the old bonds are adopted simultaneously with bondholders exchanging their old bonds for the new debt instruments, they are known as 'exit consents'. Exit consents were used in restructuring junk bonds in the 1980s, but Ecuador in 1999 seems to have been the first country to use the technique to restructure sovereign bonds.

3 This is the term given to clauses allowing a bondholders' meeting to be convened to consider a debt reconstruction, rules allowing interest and amortization terms to be modified by a qualified majority of bondholders, sharing clauses, etc. 
Exit consents have one great advantage over collective action clauses. They can be used to deal with the stock of old bonds, rather than simply allowing today's new issues to be restructured in the future. They also have one great disadvantage: that they do not give total protection against the threat of litigation by holdouts. An optimal strategy for an emerging market (or at least for one with a reputation as a good creditor) would be to ensure that all new bonds contain collective action clauses, while being ready to use exit consents on old bonds should the need arise. It would be very easy to ensure that its new bonds contain such clauses: all it need do is shift its borrowing to London until New York law is amended so that the terms of its standard bond contract include collective action clauses.

Might the inclusion of collective action clauses in bond contracts actually make bonds more attractive for creditors to hold as well as making life easier for debtors if the worst materializes? That depends on the net outcome of two opposing considerations. On the one hand, collective action clauses will reduce the cost and disruption of debt restructuring should the debtor become unable to pay on the originally contracted terms. On the other hand, the greater ease of renegotiating terms may encourage a debtor to succumb to the temptation to avoid paying when it could have done. The evidence on bond pricing of Eichengreen and Mody implies that investors are able to discriminate between the countries in which each effect dominates, which suggests that they are unlikely to suffer if collective action clauses become routine. By making more explicit the possibility that bonds will have to be restructured, one would expect collective action clauses to make potential buyers weigh the chances that they will be invoked, which will help to curb short-termism. Those who still buy them are therefore more likely to prove patient holders.

\section{Currency of denomination}

One reason that currency crises tend to be so disruptive is that foreign lending to an emerging market country is virtually always denominated in either dollars or (if different) the currency of the lender. This means that any devaluation increases the borrowing country's foreign liabilities in terms of its domestic currency, which can, in extreme cases, threaten widespread bankruptcy in the financial and/or corporate sectors (as happened in East Asia in 1997). In contrast, many industrial countries do borrow predominantly in their own currencies, which makes an exchange-rate change far less threatening.

One change that would therefore seem highly desirable would be to use the borrower's currency to denominate international loans. Eichengreen and Hausmann (1999) have implied that this is inconceivable by describing emerging market countries as suffering 'original sin'. No evidence is presented to justify the innuendo that the practice of denominating loans in foreign currencies is unalterable. In fact there are occasional instances of emerging countries that borrow in their own currencies, of which the major example is South Africa. Instead of dismissing the possibility of achieving such a desirable reform, it makes more sense to try and understand why it happens so rarely and, thereby, what conditions might be necessary to make it the norm. 
Why might lenders seek to avoid currency exposure? The strongest reason is a desire to avoid holding assets in a currency whose authorities have a record of irresponsible macroeconomic management that may lead to unpredictable losses through devaluation. But most emerging markets have got beyond the stage where they imagine that cheating their creditors is a clever strategy. Since most emerging market countries have domestic interest rates higher than dollar interest rates at most times, the expectation would be that a lender would earn more from loans denominated in the borrowers' currency in normal times. Indeed, there is a presumption that the currency risk premium would in the long run tend to make domestic currency borrowing more expensive to the borrower and more remunerative to the lender. What it would accomplish, is to redistribute obligations to pay away from times when payment is particularly onerous to those when it is less problematic. Agreement to denominate loans in the local currency would essentially redistribute earnings over time, in such a way as to diminish the pressures on the borrowers at particularly difficult times, without diminishing - indeed, while probably increasing - the present value of expected earnings. A lender that was particularly concerned to avoid showing a balance-sheet loss could cover its position in the forward market (whether the borrowing country would still reduce its risks in the event of a devaluation would depend on whether the cover was provided by a domestic or foreign party). This suggests that it is pretty difficult to justify lenders' obsession with avoiding foreign currency exposure.

The greater security of own-currency borrowing was already recognized by the 1988 Basel Accord, which allowed the preferential 20 per cent risk weight to apply to longterm bank lending in non-OECD countries when it was denominated in, and financed in, the local currency. The policy question is whether the industrial countries should not go further and drop the requirement that the lending be financed by local currency deposits or borrowing, and thus give an incentive for foreign lending to be denominated in the local currency.

\section{Remuneration practices}

Most managers in the asset management business face a remuneration structure that is intended to align their personal incentives with the welfare of their principals. This takes the form of a base salary that is augmented by the possibility of earning a substantial bonus for superior performance. The base salary is intended to secure a reasonable standard of living for the manager even if his performance is normal, while the bonus pays him a part of the benefit that would accrue to his principal if his returns are exceptional, thus providing him with an incentive to strive to achieve such exceptional returns. The bonus is normally based on the extent to which the portfolio he manages achieves a higher return than the norm for the asset class in which he is investing, as measured by the index for that asset class.

The problem with this solution is that the time frame over which bonuses are defined may not be long enough for a contrarian investment policy to bear fruit. If bonuses were paid annually and fads lasted only a few months, then the bonus system would give a manager the right incentives. But if bonuses are paid on an annual basis (or worse, as is normal in mutual funds, quarterly), while fads can last for years at a time, then a responsible investment manager who makes long-term contrarian investments can find himself foregoing bonuses for long periods. Worse, he may risk getting fired for falling 
behind the index for a period shorter than a fad can last. The bonus system is an attempt to respond to a real problem of making sure that managers act in the interest of their principals, but it can provide an incentive for managers to compete to beat the index in the short run and make sure they do not depart too far from it in the longer run, a behaviour that can amplify and prolong fads.

The importance attached to a manager's performance relative to his/her chosen benchmark has the unfortunate result of inducing herd behaviour on the part of managers. However strongly s/he may believe a security to be misvalued by the market, $\mathrm{s} /$ he simply cannot afford to follow his/her convictions if $\mathrm{s} / \mathrm{he}$ believes that the crowd is going to perpetuate its error for any length of time. That way s/he risks not merely his or her bonus, but even his or her job. Professional prudence dictates not straying too far from the benchmark, i.e. not defying the herd.

Since the problem is that the bonus design gives an incentive to follow the herd in the short run without paying proper attention to the likely long-run consequences of where the herd is heading, it seems natural to explore the possibility of introducing longer-run performance into the design. Suppose, for example, that a manager were paid their bonus only with a delay, and then only if subsequent events had not established that his/her investment strategy was flawed. This would provide a very concrete incentive to assess the longer-term sustainability of the strategy s/he was choosing to pursue. And it would not be difficult to use tax policy to encourage all asset management organizations to revise their remuneration practices in this way: one could provide that bonuses paid more promptly or without appropriate conditionality would not count as an expense that the employer was entitled to deduct from revenue in calculating taxable profit.

Such an approach would be relatively easy if asset managers stayed in the same job for their whole career, but difficulties arise when a manager quits. One surely would not want to give an artificial incentive to accelerate turnover by paying out the bonus unconditionally to any manager who quit his/her job. Could one notionally freeze the portfolio as it was on the leaving date and apply the agreed test to that hypothetical portfolio? Since managers change their portfolios quite frequently, that would hardly seem just. Would one look at the performance achieved by his/her successor and assume that the departing manager's policy would have been the same? If that were a good assumption, one has to doubt whether it was worth changing the manager. Would one require the departing manager to continue managing a hypothetical portfolio for the succeeding five years to establish that s/he could have achieved the hurdle level of performance? This is a problem where more research is going to be needed.

An alternative approach would involve more radical change in the way the industry functions, with trustees taking a bigger part of the burden on themselves. Instead of hiring managers to make the critical decisions, and seeking to blame those managers when things go wrong, trustees could themselves decide to buy and hold for the long term. Or they could decide that a certain proportion of their portfolio was going to be invested in an asset class like emerging market bonds and then hire a manger to look after it for five or ten years, with a bonus to be determined only at the end of that period on the basis of cumulative performance over the whole period. They might even experiment with assigning a portfolio to a manager for a ten-year period and relying on his/her sense of professional responsibility to motivate him or her to act in the best longterm interest of the principals. This assumes that there are competent people who find 
that a professional challenge provides sufficient motivation for exceptional effort, without a need for monetary incentives, which is normally taken for granted in many other professional areas.

\section{Concluding remarks}

The boom-bust cycle in lending to emerging markets is exaggerated by the short-termist nature of modern financial markets and the incentives to which the individual participants in those markets are subject. While some reforms, such as getting the banks to abide by their voluntary code of conduct, may be relatively easy to achieve, most of the other easy ones (like requiring proper accounting of bonds with put options) seem unlikely to achieve a great deal. Changing remuneration patterns might be important although it looks difficult to find a formula that will work satisfactorily for those who change jobs. Perhaps the most hopeful possibility is to develop the idea of allowing standstills to be invoked in a crisis, in which context an amended UDROP clause in loan contracts might prove helpful. 


\section{References}

Barth, Michaeland Xin Zhang (1999), 'Foreign Equity Flows and the Asian Financial Crisis', in A. Harwood, R.E. Litan, and M. Pormerleano (eds), Financial Markets and Development: The Crisis in Emerging Markets (Washington, Brookings Institution).

Bekaert, Geert, Campbell R. Harvey and Robin L. Lumsdaine (1999), 'The Dynamics of Emerging Market Equity Flows', NBER Working Paper, No.7219.

Buchheit, Lee C. and G. Mitu Gulati (2000), 'Exit Consents in Sovereign Bond Exchanges', UCLA Law Review 48(1), October, pp. 59-84.

Buiter, Willem H. and Anne C. Sibert (1999), 'UDROP: A Contribution to the New International Financial Architecture', International Finance, 2(2), July, 227-48.

Choe, Hyuk, Bong-Chan Kho and Rene M. Stulz (1998), 'Do Foreign Investors Destabilize Stock Markets? The Korean Experience in 1997', NBER Working Paper, No.6661.

Claessens, Stijn, Michael Dooley and Andrew Warner (1994), 'Portfolio Capital Flows: Hot or Cool?', in M. J. Howell (ed.), Investing in Emerging Markets (London, Euromoney Publications in association with the World Bank).

Eichengreen, Barry and Richard Portes (1995), 'Crisis? What Crisis? Orderly Workouts for Sovereign Debtors', CEPR, pp. i-xviii + 134 .

Eichengreen, Barry and Ricardo Hausmann (1999), 'Exchange Rates and Financial Fragility', NBER Working Paper, No. 7418, at http://papers.nber.org/papers/W7418.pdf.

Eichengreen, Barry and Ashoka Mody (2000a), 'Would Collective Action Clauses Raise Borrowing Costs?' NBER Working Paper, No.7458.

Eichengreen, Barry and Ashoka Mody (2000b), 'Would Collective Action Clauses Raise Borrowing Costs? An Update and Extension', World Bank Working Paper, No.2363.

Ffrench-Davis, Ricardo and Heriberto Tapia (2001), 'Three Policy Varieties to Face Capital Surges in Chile', in R. Ffrench-Davis (ed.), Financial Crises in 'Successful' Emerging Economies (Santiago, McGraw-Hill and Washington, Brookings Institution).

Financial Stability Forum (2000), Part V: Report of the Market Dynamics Study Group pp.115-62, http://www.fsforum.org/Reports/Rephli.html

Froot, Kenneth, Paul O'Connell and Mark Seasholes (1998), 'The Portfolio Flows of International Investors, I', NBER Working Papers, No.6687.

Griffith-Jones, Stephany (2001), 'Capital Flows to Developing Countries: Does the Emperor Have Clothes?', Mimeo.

Kaminsky, G., R. Lyons and S. Schmukler (1999), 'Managers, Investors, and Crises: Mutual Fund Strategy in Emerging Markets', World Bank, Mimeo.

Kaufman, Henry (2000), On Money and Markets: A Wall Street Memoir (New York: McGraw Hill).

Kim, Woochan and Shang-Jin Wei (1999a), 'Foreign Portfolio Investors Before and During a Crisis', NBER Working Paper, No.6968.

Kim, Woochan and Shang-Jin Wei (1999b) 'Offshore Investment Funds: Monsters in Emerging Markets?’ NBER Working Paper, No.7133. 
Krueger, Anne (2001), 'International Financial Architecture for 2002: A New Approach to Sovereign Debt Restructuring', address given to the National Economists' Club, November 26.

Lipsey, Robert E. (2001), 'Foreign Direct Investors in Three Financial Crises', NBER Working Paper, No.8084.

Ocampo, José Antonio (2001), 'Domestic Responses to International Financial Instability', WIDER Preliminary Contribution, at http://www.wider.unu.edu.

Persaud, Avinash (2000), 'Sending the Herd Off the Cliff Edge: The Disturbing Interaction Between Herding and Market-Sensitive Risk Management Practices', winning essay in the Jacques de Larosiere Essay Competition sponsored by the Institute of International Finance.

Swensen, David (2000), 'Pioneering Portfolio Management: An Unconventional Approach to Institutional Investment', New York, The Free Press, pp.xvi + 366. 